\title{
Therapeutic keratoplasty in fungal corneal ulcers
}

\author{
GURBAX SINGH AND S. R. K. MALIK \\ Maulana Azad Medical College and Associated Irwin and G.B. Pant Hospitals, New Delhi, India
}

The incidence of fungal corneal ulcers is increasing with the widespread injudicious use of corticosteroids and antibiotics. The present communication reports the results of surgical treatment in serious cases of fungal keratitis in which medical treatment has been unsuccessful.

\section{Material and methods}

The patients were seen at the hospital clinics in the years 1964 to 1969 . Their ages ranged from 4 to 70 years, more than half of them being over $4^{0}$ years of age. The following types of fungus were seen:

$\left.\begin{array}{ll}\text { Aspergillus fumigatus } & 8 \\ \text { Fusarium } & 2 \\ \text { Candida albicans } & 5 \\ \text { Penicillium citrinum } & 2\end{array}\right\}$ Total I 7

Unfortunately most of the patients did not come to the clinic before massive hypopyon or perforation of the cornea had developed and surgery had to be attempted in order to save the eye.

PREOPERATIVE TREATMENT

In every case Hamycin eye drops (I0,00o units/ml.) were instilled locally four times a day, and Hamycin tablets were given orally (one three times a day). In one case hourly gutt. amphotericin-B ( $\mathrm{mg} . / \mathrm{ml}$.) were also given.

OPERATIVE TECHNIQUES

Lamellar keratoplasty (Table I, overleaf)

This was carried out in seven cases in which there was no perforation of the cornea. The hypopyon was drained in only one case. The diameter of the grafts varied from 7 to $10 \mathrm{~mm}$.

Penetrating keratoplasty (Table II, overleaf)

This was carried out in ten cases; in two the cornea was perforated and in eight the infected tissue could not be totally replaced by a lamellar graft. The diameter of the grafts varied from 7 to I I mm. The technique of cutting the grafts and suturing was that described by Malik and Singh (1971).

POSTOPERATIVE TREATMENT

Daily dressings were carried out with Hamycin eyedrops and atropine eye ointment for $2 \mathrm{I}$ days. Sutures were removed on the 2 ist postoperative day. 
Table I Results of lamellar keratoplasty in seven cases of fungal ulcer followed by penetrating keratoplasty in four cases

\begin{tabular}{|c|c|c|c|c|c|c|c|c|c|c|c|}
\hline \multirow[b]{2}{*}{$\begin{array}{l}\text { Case } \\
\text { No. }\end{array}$} & \multirow[b]{2}{*}{$\begin{array}{l}\text { Age } \\
(y r s)\end{array}$} & \multirow[b]{2}{*}{ Sex } & \multirow[b]{2}{*}{ Fungus } & \multirow[b]{2}{*}{ Graft } & \multirow[b]{2}{*}{$\begin{array}{l}\text { Size } \\
(\mathrm{mm} .)\end{array}$} & \multicolumn{2}{|l|}{ Visual acuity } & \multirow[b]{2}{*}{$\begin{array}{l}\text { Status of } \\
\text { infection }\end{array}$} & \multicolumn{3}{|l|}{ Graft } \\
\hline & & & & & & Preoperative & $\begin{array}{l}\text { Post- } \\
\text { operative }\end{array}$ & & $\begin{array}{l}\text { Trans- } \\
\text { parent }\end{array}$ & $\begin{array}{l}\text { Semi- } \\
\text { trans } \\
\text { parent }\end{array}$ & Opaque \\
\hline I & 45 & $\mathbf{M}$ & Aspergillus & $\begin{array}{l}\text { Lamellar } \\
\text { Lamellar } \\
\text { Evisceration }\end{array}$ & $\begin{array}{l}8 \times 0.45 \\
9 \times 0.5\end{array}$ & $\begin{array}{l}\text { PL } \\
\text { accurate }\end{array}$ & PL & $\begin{array}{l}\text { Not controlled } \\
\text { Not controlled }\end{array}$ & - & - & - \\
\hline 2 & 50 & $\mathbf{M}$ & $\begin{array}{l}\text { Candida } \\
\text { albicans }\end{array}$ & Lamellar & $9 \times 0 \cdot 5$ & $\begin{array}{l}\text { PL } \\
\text { accurate }\end{array}$ & $6 / 18$ & Controlled & $\begin{array}{l}\text { Yes } \\
\text { (Fig. I) }\end{array}$ & - & - \\
\hline 3 & 38 & $\mathbf{F}$ & Aspergillus & Lamellar & 7 & $\begin{array}{l}\text { PL } \\
\text { faulty }\end{array}$ & No PL & Not controlled & - & - & - \\
\hline 4 & 50 & $\mathbf{M}$ & Aspergillus & $\begin{array}{l}\text { Lamellar } \\
\text { Lamellar } \\
\text { Penetrating } \\
\text { Evisceration }\end{array}$ & $\begin{array}{l}8 \times 0.45 \\
9 \times 0.5 \\
10\end{array}$ & $\begin{array}{l}\text { PL } \\
\text { faulty } \\
\text { CF }\end{array}$ & $\begin{array}{l}\text { GF } \\
\text { PL }\end{array}$ & $\begin{array}{l}\text { Not controlled } \\
\text { Not controlled } \\
\text { Not controlled }\end{array}$ & $=$ & $=$ & $\bar{z}$ \\
\hline 5 & 70 & $\mathbf{M}$ & $\begin{array}{l}\text { Candida } \\
\text { albicans }\end{array}$ & $\begin{array}{l}\text { Lamellar } \\
\text { Penetrating }\end{array}$ & $\begin{array}{l}8 \\
9\end{array}$ & $\stackrel{P L}{C F}$ I m. & $\begin{array}{l}\text { PL } \\
\mathbf{C F}\end{array}$ & $\begin{array}{l}\text { Not controlled } \\
\text { Controlled }\end{array}$ & - & - & Yes \\
\hline 6 & 38 & $\mathbf{F}$ & Astergillus & $\begin{array}{l}\text { Lamellar } \\
\text { Penetrating }\end{array}$ & $\begin{array}{r}9 \\
\mathbf{9}\end{array}$ & $\stackrel{P L}{C F} \times \mathbf{m}$. & $\begin{array}{l}\text { PL } \\
\text { CF }\end{array}$ & $\begin{array}{l}\text { Not controlled } \\
\text { Controlled }\end{array}$ & Yes & - & - \\
\hline 7 & 22 & $\mathbf{M}$ & $\begin{array}{l}\text { Candida } \\
\text { albicans }\end{array}$ & $\begin{array}{l}\text { Lamellar } \\
\text { Lamellar } \\
\text { Penetrating }\end{array}$ & $\begin{array}{r}9 \\
10 \\
10\end{array}$ & $\begin{array}{l}\text { GF } \\
\text { CF }\end{array}$ & $\begin{array}{l}\text { GF } \\
\text { GF } \\
6 / 60\end{array}$ & $\begin{array}{l}\text { Not controlled } \\
\text { Not controlled } \\
\text { Controlled }\end{array}$ & $\begin{array}{l}\overline{ } \\
\overline{\text { Yes }} \\
\text { (Fig. 2) }\end{array}$ & $\begin{array}{l}- \\
-\end{array}$ & - \\
\hline
\end{tabular}

Table II Penetrating keratoplasty in ten cases of fungal corneal ulcer as the primary procedure

\begin{tabular}{|c|c|c|c|c|c|c|c|c|c|c|c|}
\hline \multirow[b]{2}{*}{$\begin{array}{l}\text { Case } \\
\text { no. }\end{array}$} & \multirow[b]{2}{*}{$\begin{array}{l}\text { Age } \\
(\text { yrs })\end{array}$} & \multirow[b]{2}{*}{ Sex } & \multirow[b]{2}{*}{ Type of ulcer } & \multirow[b]{2}{*}{ Fungus } & \multirow{2}{*}{$\begin{array}{l}\text { Size of } \\
\text { graft } \\
(\mathrm{mm} .)\end{array}$} & \multicolumn{2}{|c|}{ Visual acuity } & \multirow[b]{2}{*}{$\begin{array}{l}\text { Slatus of } \\
\text { infection }\end{array}$} & \multicolumn{3}{|l|}{ Graft } \\
\hline & & & & & & $\begin{array}{l}\text { Pre- } \\
\text { operative }\end{array}$ & $\begin{array}{l}\text { Post- } \\
\text { operative }\end{array}$ & & $\begin{array}{l}\text { Trans- } \\
\text { parent }\end{array}$ & $\begin{array}{l}\text { Semi- } \\
\text { trans- } \\
\text { parent }\end{array}$ & Opaque \\
\hline I & 26 & $\mathbf{F}$ & Hypopyon & Aspergillus & 9 & PL faulty & $6 / 18$ & Controlled & $\begin{array}{l}\text { Yes } \\
\text { (Fig. 3) }\end{array}$ & - & - \\
\hline 2 & 4 & $\mathbf{F}$ & Hypopyon & Aspergillus & 7 & PL faulty & HM & Controlled & - & - & Yes \\
\hline 3 & 45 & $\mathbf{M}$ & Hypopyon & Candida & $8-10$ & PL faulty & HM & Controlled & - & - & Opaque \\
\hline 4 & 28 & $\mathbf{M}$ & Hypopyon & Aspergillus & 8 & PL faulty & $6 / 60$ & Controlled & - & $\overline{\text { Yes }}$ & - \\
\hline 5 & 30 & $\mathbf{F}$ & Hypopyon & Aspergillus & 9 & PL faulty & CF & Controlled & - & - & Opaque \\
\hline 6 & 52 & $\overline{\mathbf{M}}$ & Hypopyon & Fusarium & 8 & PL faulty & $\overline{\mathrm{CF}}$ & Controlled & Yes & - & - \\
\hline 7 & 60 & $\mathbf{M}$ & Hypopyon & Fusarium & 9 & PL faulty & PL & Yes & Clear & - & - \\
\hline 8 & 50 & $\overline{\mathbf{M}}$ & Hypopyon & Penicillium & 8 & PL faulty & $\overline{\mathrm{HM}}$ & Yes & - & Yes & $\overline{-}$ \\
\hline 9 & 60 & $\mathbf{M}$ & Hypopyon & Candida & II & PL faulty & $6 / 60$ & Yes & - & Yes & $\overline{-}$ \\
\hline 10 & 40 & $\mathbf{F}$ & $\begin{array}{l}\text { Perforated } \\
\text { corneal }\end{array}$ & Penicillium & 9 & $\begin{array}{l}\text { PL } \\
\text { accurate }\end{array}$ & CF & Yes & - & - & Opaque \\
\hline
\end{tabular}

\section{Observations}

\section{A. LAMELLAR KERATOPLASTY (Table I)}

\section{Results}

Of seven cases only one (Case 2) was controlled by this procedure with improvement in $\frac{7}{0}$ visual acuity (Fig. $1 a, b$ ). In three (Cases $5,6,7$ ) the eye was saved structurally by a $\stackrel{\mathbb{D}}{\mathbb{D}}$ subsequent graft (Fig. 2a,b,c). In Gase I the eye was lost through re-infection after a $\stackrel{\mathbb{Q}}{\varnothing}$ second lamellar graft. In Case 3 the eye remained blind. In Case 4 the eye was lost after a second lamellar graft and a subsequent penetrating graft. 
( I a)

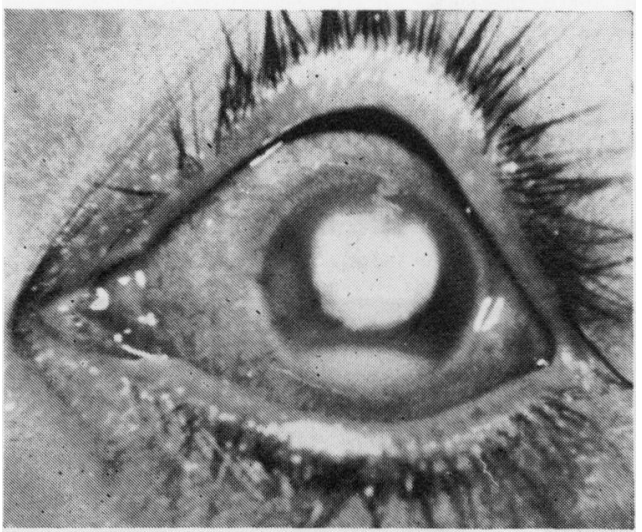

( Ib)

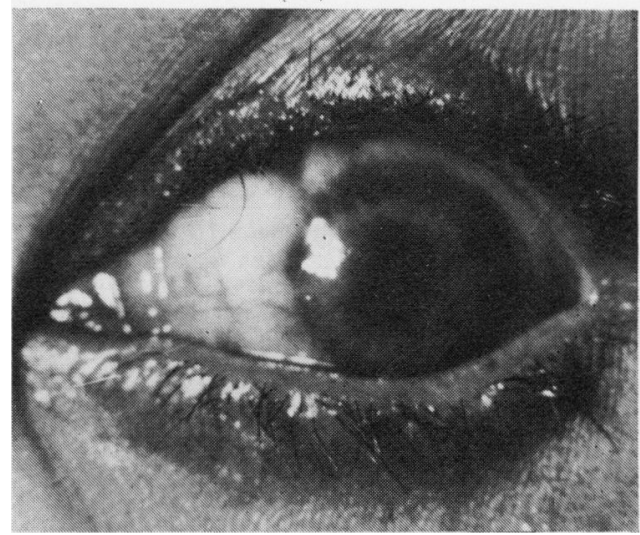

FIG. Ia Preoperative appearance of fungal hypopyon corneal ulcer (Case 2, Table I)

FIG. Ib Clear lamellar graft (Case 2, Table I)

\section{Postoperative complications}

Re-infection of the graft, which was seen in six cases, appeared after 48 hours in the form of small white dots in the bed of the graft (Fig. $2 b$ ). These dots increased in number and size in the next few days with increase in hypopyon, but the eye was successfully treated with a penetrating graft (Fig. $2 c$ ).

(2a)

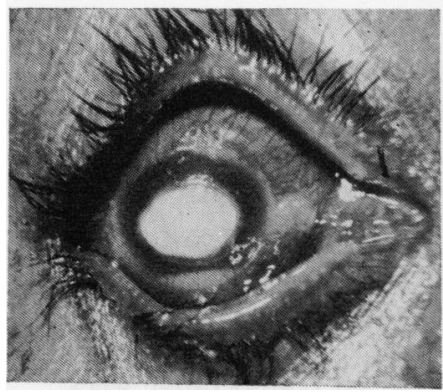

(2b)

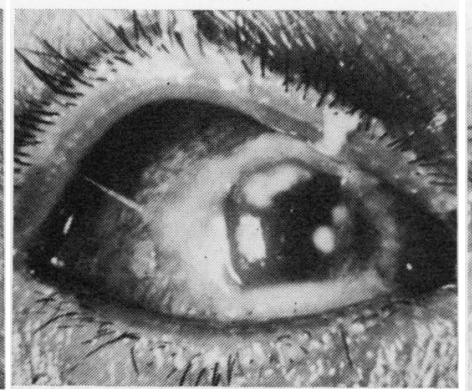

(2c)

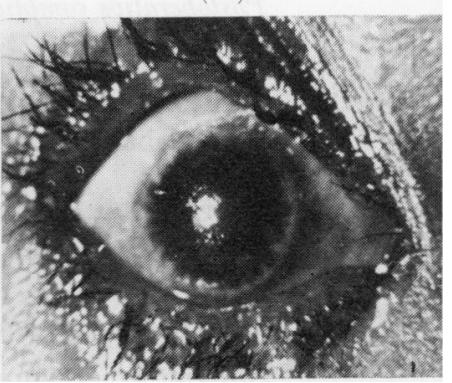

FIG. 2a Preoperative appearance of fungal ulcer (Case 7, Table I)

FIG. 2b Fungal infection in graft bed. Dots appear on third day after lamellar keratoplasty (Case 7, Table I)

FIG. 2c Successful penetrating graft (Case 7, Table I)

In each of these severe cases the cornea looked transparent after the operation and remained so for at least 48 hours. Some of these patients had visual improvement at the first postoperative dressing after 24 hours, but six of them became re-infected (Table I). The initial clarity of the graft is a deceptive sign in such cases compared with cases of pyogenic ulcer, in which once clarity is achieved the chance of re-infection is very rare (Malik and Singh, I97I). The re-infection is probably due to the fact that the fungus can penetrate the intact Descemet's membrane (Kaufman and Wood, 1965). Of the six reinfected cases, one eye was lost after a second lamellar graft, and in four others a penetrating keratoplasty was carried out as a second procedure. Three of these eyes were saved, but one was lost. 
B. PEnetrating keratoplasty as a primary progedure (Table II)

\section{Results}

Nine out of ten eyes were saved structurally with control of infection (Fig. $3 a, b, c)$. Visual acuity improved to 6/18 in one case (Case $I$ ) and to 6/6o in two cases (Cases 4 and 9).

In three cases the graft became opaque, but the infection was controlled.
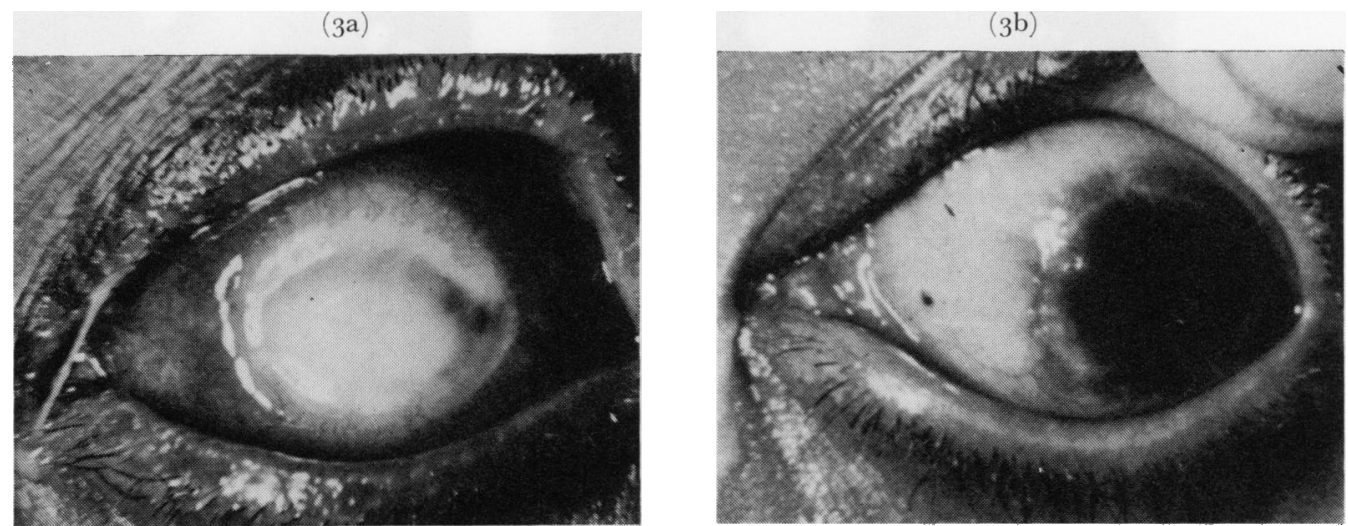

FIG. 3a Preoperative appearance of perforated fungal ulcer (Case I, Table II)

F IG. 3 b Clear penetrating graft (Case I, Table II)

\section{Postoperative complications}

IRITIS (4 cases)

Controlled by a subconjunctival injection of mydricaine and other nonspecific treatment, e.g. oxyphenbutazone.

E PITHeLial ulgers (6 cases)

Controlled by medical treatment.

ANTERIOR SYNEGHiAE (4 cases)

Anterior synechiotomy was successfully carried out in the 3 rd postoperative week.

INFECTION (I case)

Successfully controlled by regrafting on the $4^{\text {th }}$ postoperative day (Case 3 ), but the graft became opaque.

Although all but one of these eyes were saved structurally, a visual acuity of $6 / 60$ or more was achieved in only three cases. In the remaining seven cases the eyes were fit enough for subsequent regrafting in an attempt to improve the vision.

\section{Discussion}

Anderson, Roberts, Gonzales, and Chick (1959), Kaufman and Wood (1965), and Barrios (1965) were also of the opinion that lamellar keratoplasty was not a procedure of choice in fungal ulcers as it led to delay in treatment with resultant loss of the eye, though Leigh ( 1966 ) has stated that lamellar keratoplasty may be carried out in cases which have failed to respond to medical treatment. Sanders (1970) obtained good improvement in 
visual acuity with penetrating grafts in three out of fifteen cases of fungal corneal ulcer. In the remaining twelve cases infection was controlled, but they were unfit for subsequent re-grafting because of secondary complications.

\section{Summary}

Keratoplasty was carried out in seventeen cases of fungal keratitis and the following conclusions were drawn:

(I) Penetrating keratoplasty is the procedure of choice; this controls the infection and improves the visual acuity.

(2) Lamellar grafting invariably fails, because the fungus is able to penetrate Descemet's membrane.

\section{References}

ANDerson, B., Roberts, s. s., JR., gonZales, c., and chick, E. w. (1959) A.M.A. Arch. Ophthal., 62, 169

Barrios, R. R. (1965) In "The Cornea World Congress: Papers presented at the First World

Congress on the Cornea, Washington, D.C., 1964", ed. J. H. King and J. W. McTigue, p. 449. Butterworths, London

Kaufman, H. E., and wood, R. м. (1965) Amer. F. Ophthal., 59, 993

LEIGH, A. G. (I966) "Corneal Transplantation", ist ed. Blackwell, Oxford

MALIK, s. R. K., and SINGH, G. (197I) Brit. J. Ophthal., 55, 326

SANDERs, N. (1970) Amer. F. Ophthal., 70, 24 